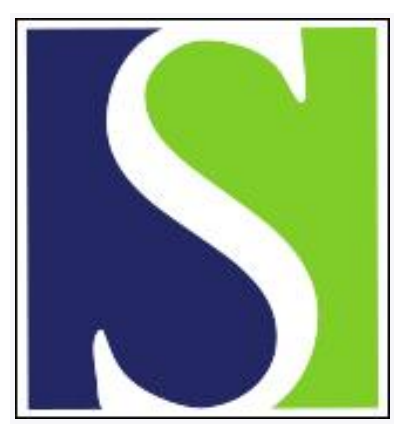

Scand J Work Environ Health 1994;20(4):306-308

https://doi.org/10.5271/sjweh.1393

Issue date: 01 Aug 1994

Erythropoietin-independent colonies of red blood cells and leukocytosis in a worker exposed to low levels of benzene.

by Froom P, Dyerassi L, Cassel A, Aghai E

Affiliation: Institute of Hematology and Blood Bank, Lady Davis Carmel Hospital and Shemer Institute, Haifa, Israel.

This article in PubMed: www.ncbi.nlm.nih.gov/pubmed/7801077

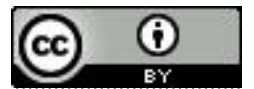




\title{
Erythropoietin-independent colonies of red blood cells and leukocytosis in a worker exposed to low levels of benzene
}

\author{
by Paul Froom, MD, Leo Dyerassi, MD, Aliza Cassel, PhD, Ester Aghai, MD1
}

\begin{abstract}
FROOM P, DYERASSI L, CASSEL A, AGHAI E. Erythropoietin-independent colonies of red blood cells and leukocytosis in a worker exposed to low levels of benzene. Scand $J$ Work Environ Health 1994;20:306-8.

BaCKGround - Exposure to high levels of benzene commonly results in the suppression of hemopoiesis, although cases of leukocytosis and leukocytosis with thrombocytosis have been reported. No hematologic abnormalities have generally been found with exposure to low levels of benzene.

Methons - A pipe fitter exposed to low levels of benzene (time-weighted average $0.9 \mathrm{ppm}$ ) developed leukocytosis. His blood counts and growth of erythroid burst forming units (BFU-E) was followed with and without the addition of erythropoietin.

Results - Erythropoietin-independent BFU-E colonies were increased to 40 per $4 \times 10^{4}$ cells (normal $<3$ per $4 \times 10^{4}$ cells). Both the leukocyte count and the number of erythropoietin-independent BFU-E colonies decreased when exposure to benzene was terminated. On reexposure the white blood count again increased. After the work was terminated, the white blood count returned to normal, as did the number of erythropoietin-independent BFU-E colonies, over a period of 12 months.

Conclusions - Our findings suggest that even low levels of benzene can result in perturbations of the hemopoietic system. Further studies are warranted to determine whether these findings are idiosyncratic, coincidental, or a more general phenomenon.
\end{abstract}

KEY TERMS - benzene, erythroid colonies, leukocytosis, low exposures.

Although exposure to benzene generally results in the suppression of hemopoiesis, cases of leukocytosis and leukocytosis with thrombocytosis have been reported (1). Aksoy et al investigated 217 apparently healthy workers exposed to concentrations of benzene between 30 and $210 \mathrm{ppm}$ for 3 months to 17 years. Five workers were found to have isolated leukocytosis, and two had leukocytosis with concomitant thrombocytosis (1). On the other hand, Townsend \& Fishbeck (2) studied 282 men, most having been exposed to less than $10 \mathrm{ppm}$ for less than 1 year to over 20 years, and none of them were found to have either leukocytosis or thrombocytosis. Still those exposed showed a trend towards a higher white blood cell count than the reference group did. Fishbeck et al (3) studied 10 workers exposed to varying concentrations of benzene and found one worker with intermittent leukocytosis. Collins et al (4) studied 200 persons exposed to $0.01-1.4 \mathrm{ppm}$; yet all but two workers were exposed to less than 0.2 $\mathrm{ppm}$. They found no difference in the mean white blood cell values of those exposed to benzene and 268 unexposed workers at the same plant.

It has been demonstrated in vitro that the proliferation of erythroid colonies from peripheral blood

I Institute of Hematology and Blood Bank, Lady Davis Carmel Hospital and Shemer Institute, Haifa, Israel.

Reprint requests to: Dr P Froom, Maagan Michael DN, Menashe 37805, Israel. and bone marrow of patients with myeloproliferative disorders occurs without the addition of exogenous erythropoietin $(5-10)$, even in those with normal total red blood cell mass. This phenomenon has been related to hypersensitivity of the erythroid stem cell to erythropoitin (8) and interleukin-3 (9). Monocytes may promote this independence (10).

In the present case study we investigated the ability of the peripheral blood of a 43-year-old fitter with exposure to benzene and leukocytosis to produce in vitro erythropoietin-independent burst-forming unit (BFU-E) colonies, as has been found in myeloproliferative disorders.

\section{Case}

A 43-year-old fitter was employed in maintenance work at a terminal for the shipping of chemicals in the Haifa harbor over a 10 -year period. His job required joining, cleaning, and repairing pipelines. His chemical exposure included benzene (3\% by volume), toluene, xylene, phenol, methyl chloride, white spirit, acetone, ethylacetate, amyl alcohol, and inorganic acids. His personal level of benzene exposure was found to be $0.9 \mathrm{ppm}$ (time-weighted average), and that of phenol was $0.1 \mathrm{ppm}$. Monitoring tests are done in the harbor every three months and the time-weighted averages for benzene in the areas where he worked ranged from 0.3 to $1.2 \mathrm{ppm}$ over the last year. During a routine annual examination, he was found to have a white blood cell 
count of $15100 \cdot \mathrm{mm}^{-3}$, with a normal differential count.

Repeated testing revealed a consistently elevated count (figure 1). The leukocyte alkaline phosphatase score was elevated on two separate occasions (230 and 300 with a control of $58, N<100$ ). In a urine collection the phenol level was found to be $36 \mathrm{mg} \cdot \mathrm{I}^{-1}$.

\section{Methods}

Peripheral blood was collected with preservative-free heparin. Low-density mononuclear cells were isolated by fractionation on Ficoll-Hypaque density gradient, washed with phosphate-buffered saline, and resuspended in Iscove medium supplemented with $10 \%$ fetal calf serum. BFU-E colonies were grown from peripheral blood according to a microwell modification of the methylcellulose technique (10). Lowdensity mononuclear cells $\left(4 \times 10^{4}\right.$ cells per $\left.\mathrm{ml}\right)$ were suspended in Iscove's modified Dulbecco's medium (Biological Industries, Kibbutz Beth Haemek, Israel) with $0.8 \%$ methylcellulose, $10 \%$ fetal calf serum, $0.01 \%$ 5-thioglycerol, and a penicillin-streptomycin solution. BFU-E colonies were scored after $14 \mathrm{~d}$ of incubation in a fully humidified atmosphere with $5 \%$ carbon dioxide at $37^{\circ} \mathrm{C}$. The colonies with at least three clusters of 50 cells were defined as BFU-E. Selected colonies were stained with benzidine for the identification of their erythroid lineage; otherwise they were identified by their reddish color.

\section{Results}

The number of erythropoietin-independent BFU-E colonies was increased to 40 per $4 \times 10^{4}$ cells (normal $<3$ per $4 \times 10^{4}$ ). When the exposure to benzene was terminated, the BFU-E (erythropoietin-independent) decreased to 20 and then to 7 and the leukocyte counts returned to normal. After reexposure, the patient's leukocyte count again increased to over 18000 . He has subsequently stopped working and stopped smoking, and his leukocyte count has remained normal over a year of follow-up. The erythropoietin-independent BFU-E colonies decreased to 2 per $4 \times 10^{4}$. The leukocyte alkaline phosphatase scores also returned to normal.

\section{Discussion}

Leukemogenesis is thought to be a multistep process. Whether the findings from our patient represent one reversible step in the carcinogenic process is uncertain, however. Benzene has been shown to activate protein kinase $\mathrm{C}$ both in vitro and in intact platelets (11). Protein kinase $\mathrm{C}$ plays a central role in signal transduction and is thought to mediate several tumor promoters (12). Introducing oncogenically activated receptor kinases has been shown to alleviate completely the requirements for epidermal

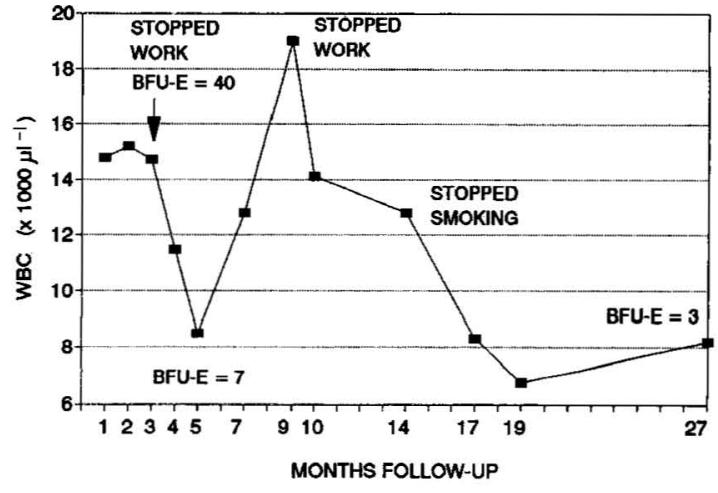

Figure 1. White blood count (WBC) of the patient after work was stopped on two occasions. The erythropoietin-independent erythroid burst forming units (BFU-E) decreased from 40 to 3 per $4 \times 10^{4}$ cells after work and smoking were stopped.

growth factor for the growth of mouse keratinocytes (13). This finding may be analogous to our finding of the erythropoietin-independent growth of red cell progenitor colonies. A rapid decrease in the incidence of leukemia when exposure to benzene is terminated has been reported and is consistent with the finding of a reversible step in the carcinogenic process (14). Finally, two cases of chronic myelogenous leukemia have been reported among workers exposed to high levels of benzene (14).

Our results should be interpreted with caution. The fitter was exposed to many other chemicals, and our findings could have been a result of exposure to one of these chemicals or merely coincidental. Still perturbations in the hemopoietic system have not been reported with the other chemicals. There are many causes of leukocytosis, such as mild chronic infections, inflammatory diseases, and allergic reactions. Our patient however was asymptomatic. The work challenge test was positive, and no leukocytosis was found during the follow-up after the exposure was terminated. Therefore we believe that benzene was likely to be responsible for the effects noted. Further studies of workers with and without leukocytosis and exposed to low levels of benzene are warranted in order to substantiate our findings. Animal studies and epidemiologic studies have suggested that the "no effect" exposure level for the hematologic effects of benzene in humans is $25 \mathrm{ppm}$, the timeweighted average suggested by the American Conference of Governmental Industrial Hygienists (4). In a study of workers exposed chronically to levels under $1 \mathrm{ppm}$ with occasional levels over $100 \mathrm{ppm}$, no effects were found on hematologic or biochemical parameters, proliferative rate indices, sister chromatid exchanges, and urine mutagenicity, except for a small but significant increase in mean corpuscular volume (15). Such tests may, however, lack sensitivity.

It is uncertain whether our findings were idiosyncratic or a general phenomenon related to the devel- 
opment of malignancy. We are planning a study of progenitor cells in a cohort of workers exposed to low levels of benzene. Since the abnormalities found in our patient were reversible, it is unlikely that he is at increased risk for developing leukemia. Still he is possibly more sensitive to the effects of benzene than other workers, and we have recommended that he not be returned to work in areas where there are even low exposure levels of benzene.

\section{References}

1. Aksoy M, Dincol K, Akgun T, Erdem S, Dincol G. Haematological effects of chronic benzene poisoning in 217 workers. Br J Ind Med 1971;28:296-302.

2. Townsend JC, Ott G, Fishbeck WA. Health exam findings among individuals occupationally exposed to benzene. J Occup Med 1978;20:543-8.

3. Fishbeck WA, Townsend JC, Swank MG. Effects of chronic occupational exposure to measured concentrations of benzene. J Occup Med 1978;20:539-42.

4. Collins JJ, Conner P, Friedlander BR, Easterday PA, Nair RS, Braun J. A study of the hematological effects of chronic low-level exposure to benzene. J Occup Med 1991;33:619-26.

5. Prechal JF, Adamson LW. Polycythemia vera: the invitro response of normal and abnormal stem cell lines to erythropoietin. J Clin Invest 1978;61:1044-7.

6. Eaves AC, Eaves CJ. Abnormalities in the erythroid progenitor compartments in patients with chronic myelogenous leukemia (CML). Exp Hematol 1979; 7 (supp 1):65-74.
7. Partanen S, Ruutu T. Vuopio P. Haematopoietic progenitors in essential thrombocythemia. Scand $\mathbf{J} \mathrm{Hae}-$ matol 1983;30:130-4.

8. Eaves CJ, Eaves AC. Erythropoietin (Ep) dose response curve for three classes of erythroid progenitors in normal human marrow and in patients with polycythemia vera. Blood 1978;52:1196-210.

9. Dai CH, Lrentz SB, Dessypris EN, Means RT, Horn ST, Gilbert HS. Polycythemia vera II: hypersensitivity of bone marrow erythroid, granulocyte, macrophage and megakaryocyte progenitor cells to interleukin-3 and granulocytic macrophage colony stimulating factor. Blood 1992;80:891 9 .

10. Shabbad E, Cassel A, Froom P, Aghai E. Defect of adherent cells on the regulation of BFU-E in patients with myeloproliferative disease. Am J Hematol 1990; $33: 225-9$.

11. Da Salva C, Fan XT, Castagna M. Benzene-mediated protein kinase $\mathrm{C}$ activation. Environ Health Perspect 1989;82:91-5.

12. Berridge $A$, Irvine RF. Inositol phosphates and cell signalling. Nature 1989;341:197-204.

13. Aaronson SA. Growth factors and cancer. Science 1991;254:1146-52.

14. Aksoy M. Hematotoxicity and carcinogenicity of benzene. Environ Health Perspect 1989;82:193-7.

15. Yardley Jones A, Anderson D, Jenkinson PC, Lovell DP, Blowers SD, Davies MJ. Genotoxic effects in peripheral blood and urine of workers exposed to low levels of benzene. $\mathrm{Br} J$ Ind Med 1988;45:694-700.

Received for publication: 17 August 1993 